\title{
STRUCTURAL DIFFERENTIATION AND ORGANISATIONAL LEARNING CAPABILITY AS PREDICTORS OF CORPORATE VENTURING AND BUSINESS GROWTH AMONG SMES IN SOUTH AFRICA
}

\author{
Ralebitso Kenneth Letshaba \\ Vaal University of Technology \\ Eugine Tafadzwa Maziriri \\ University of the Free State \\ Tinashe Ndoro \\ University of Pretoria \\ Tinashe Chuchu* \\ University of Pretoria
}

\begin{abstract}
In this ever-changing business milieu, growth is generally perceived positively for business as it is considered a measure of success and a key driver in the creation of wealth, employment, and economic development. This paper therefore investigates the relationship between structural differentiation, organisational learning capability, co-operative venturing and business growth from the perspective of SME managers. To this end, a unique conceptual model was developed and empirically tested. The survey method was adopted where a questionnaire was administered to SME managers within the Gauteng province of South Africa. Data analysis was conducted using SPSS 25 and Smart PLS 3.0 to generate the sample profile and to test the proposed hypothesis, respectively. Organisational learning capabilities had a noticeably stronger impact on successful corporate venturing as compared to structural differentiation, suggesting that SMEs have to invest more resources toward improving employees' knowledge of the job within their respecting roles within SMEs.
\end{abstract}

Keywords: Structural differentiation; Organisational learning capability; Corporate venturing; Business growth; Small and medium enterprises.

Received: 19 March 2019

Accepted: 13 January 2020

\section{INTRODUCTION}

Global economies have acknowledged Small and medium enterprises (SMEs) as vehicles of development because of their critical commitment to poverty alleviation, work creation and improvement in the standard of living (Arthur-Aidoo, Aigbavboa \& Thwala, 2018; Kongolo, 2010). With regards to South Africa, SMEs have been recognised to represent generally $52 \%$ to

*Corresponding author: Department of Marketing Management, Faculty of Economic and Management Sciences, University of Pretoria.Email: tinashe.chuchu@up.ac.za 
$57 \%$ of South Africa's (GDP) and contributed a projected $61 \%$ to work creation over the years (Mafini \& Loury-Okoumba, 2018). One of the critical qualities of a thriving and developing economy is a prospering SMEs sector. Small and medium enterprises assume an essential part in the development of a country (Feeney \& Riding, 1997). SMEs contribute to economic development in various ways: by creating opportunities in rural and urban developing areas, providing desirable sustainability and innovation in the economy. In addition to that, a substantial number of people depend on SMEs directly or indirectly (Fida, 2008). The development of SMEs is viewed as the best approach to accelerating the accomplishment of more extensive socio-economic objectives (Kongolo, 2010). In this study, we examine structural differentiation and organisational learning capability on corporate venturing and business growth among SMEs. Differentiation is a general idea with a wide variety of aspects, such as role differentiation, rank or status differentiation and differentiation of formal organisations (Farrel, 1969; Golden \& Ma, 2003). Businesses can grow through separating teams that pursue different goals through a process known as structural differentiation (Hanks 2019). According to Golden and Ma (2003), structural differentiation refers to differences that exist within sub-units based on goal orientation, time orientation, and interpersonal orientation throughout the organisation. The concept 'structural differentiation' is not new and is connected to the basic components of a social system (Farrel, 1969). Structural differentiation can be thought of as both a procedure and a condition. As a procedure, it alludes to the reduplication of one basic structure into at least two fundamentally unique components, and to the setting up of increasingly particular and progressively independent social units. As a condition, structural differentiation refers to the quantity of structurally distinctive specific components which exist in a system at a specific point in time (Farrel, 1969).

Recently, SMEs have received attention as far as organisational learning is concerned. For example, Martínez-Costa, Jiménez-Jiménez, and Dine Rabeh (2019) assessed the impact of organisational learning on inter-organisational partnerships Organisational learning is generally viewed as the procedure through which an organisation obtains new information, practises and sustains it, and uses or exploits it (Keil, 2000). Organisational learning has long been considered a metric for assessing organisational performance (Qi \& Chau, 2018). Tohidi and Mandegari (2012) consider organisational learning capability to be the organisational and managerial resources that enable the organisational learning process. The present study investigates how organisational learning capabilities influences both corporate venturing and the growth of SMEs. "Organisational learning capability is the organisational and managerial characteristics that facilitate the organisational learning process" (Tohidi \& Mandegari, 2012, p.4523). The organisational literature reveals that organisational learning capabilities have a basic influence in the improvement and advancement of organisations and builds the capability of development (Tohidi \& Mandegari, 2012). Learning has made a basic difference in organisations, and subsequently, it has developed into a fundamental subject and the sensation of the organisational learning capability has gradually turned into a basis of concern among scholars (Jyothibabu \& Farooq, 2010). An ever-increasing number of organisations have turned out to be keen on corporate venturing as an approach to organisational restoration (Keil, 2000).

Corporate venturing is a collection of organisational systems, processes and practices aimed at developing businesses in existing or new fields, markets, or industries (Narayanan, Yang \& Zahra, 2009). Corporate venturing is one of the topics of interest. Its aim is the need for firms to reestablish themselves and connect more in making new opportunities as opposed to focusing on exhausting their present capabilities (Backholm, 1999). Corporate venturing is firmly connected to 
both innovation and strategic regeneration. Some corporate venturing efforts expand upon the organisation's developments in new markets or by presenting new products. Other corporate venturing activities may prompt huge changes in an organisation's trade, systems, or focused profile, recharging the company's operations (Narayanan et al., 2009). Growth is considered by Nieman, Hough and Nieuwenhuizen (2003) as a transformation in a particular limitation over a certain period of time. In addition, growth is also viewed as a dynamic process that indicates whether organisations are static or developing (Nieman, 2006). A growing business is one that has a prominent performance and is successful, since growth opens door for organisations to expand their business, and to obtain higher profit. Hence, growth is one of the pointers used to measure the achievement of a business (Desta, 2015). Generally, the term "business growth" is utilised to allude to different things, for example, increase in total sales, increase in production capacity, increase in employment, and increase in production volume (Yeboah, 2015, p.5). These variables demonstrate growth, yet do not underline the importance of growth. Business growth is ordinarily characterised and estimated utilising total or relative changes in sales, assets, employment, productivity, and profits (Kisaka \& Mwewa, 2014).

Small businesses in South Africa do not make it past the second year of trading with failure rates as high as 63 percent (Robert, 2010). SMEs, like any other business entity, are faced with different macro factors that hamper their success and development (Cant \& Wiid, 2013). The SME sector is a central part of the national economy and, in that capacity, is consequently affected by different variables (Brink, Cant \& Ligthelm, 2003). In that perspective, SMEs are aiming to manoeuvre the volatile dynamics in the current global environment and are pressured to adopt and implement more effective business models. Emerging global interest in concepts such as, structural differentiation, organisational learning capability, corporate venturing, and business growth, reveals a number of dynamic weaknesses in earlier research, raising serious questions about their contribution to theory and practice within the SME sector of developing countries. Remarkably, regardless of expanding acknowledgment of such concepts around the world, most research has been directed at large enterprises settings that may contrast uniquely from small enterprises in the aspect of business development, strategic focus, and organisational needs (Cullen, Anderson \& Baker, 1986; Alegre \& Chiva, 2009; Narayanan et al., 2009; Schwab, Gold, Kunz \& Reiner, 2017). The above view warrants an investigation into structural differentiation and organisational learning capability as prognosticators of corporate venturing and business growth among SMEs within the Gauteng Province of South Africa.

The rest of this article is arranged as follows. The following section is a brief review of literature on the research variables. From there, the conceptual framework is presented, and hypotheses are developed. The research methodology part follows next, followed by the results and discussions, limitations, suggestions for future research, conclusions, and the managerial implications.

\subsection{Theoretical Background}

A theoretical background is provided to formulate the structure that holds the theory of a research study. The following discussion provides the theoretical background of this study. 


\subsubsection{The Resource Based View}

The Resource Based View (RBV) (Barney, 1991) is the theoretical orientation underpinning the present study. RBV purports that resources and capabilities are important for understanding the sources of sustained competitive advantage and growth by firms (Barney, Ketchen \& Wright, 2011; Wernerfelt, 1984). From the RBV, it can be noted that resources and capabilities involve bundles of tangible and intangible assets. These tangible and intangible assets include an organisation's management skills, organisational processes and routines, and the knowledge and information it controls which it uses to select and implement its strategies. The successful implementation of strategies by organisations results in a sustained competitive advantage and growth (Barney et al., 2011).

\section{LITERATURE REVIEW}

This literature review discusses the different research variables undertaken as part of this study.

\subsection{Structural Differentiation}

Structural differentiation is the degree to which activities are structurally isolated in various units in the organisation. Structurally differentiating units permits contending structures to coexist inside organisations (Gilbert, 2006), and to alter working techniques and control frameworks to the needs of a unit. The expanded opportunity improves innovativeness and knowledge creation (Burgers, Jansen, Van Den Bosch \& Volberda, 2009). Structural differentiation encourages local flexibility and exploration of novel organisations, and integrated components encourage key coherence and knowledge exchange between structurally differentiated organisational units (Gilbert, 2006; O'Reilly \& Tushman, 2004; Weick, 1982). According to Rueschemeyer (1977, p.2), "Structural differentiation is a process whereby one social role or organisation differentiates into two or more roles or organisations. The new social units are structurally distinct from each other but taken together are functionally equivalent to the original unit." Moreover, structural differentiation, or the degree of separation of manipulative and explorative practices into separate organisational units, allows each unit to execute its tasks most effectively (Raisch, Birkinshaw, Probst \& Tushman, 2009; Burgers \& Covin, 2016). Additionally, structural differentiation alludes to "the state of segmentation of the organisational system into subsystems, each of which tends to develop particular attributes in relation to the requirements posed by its relevant external environment" (Lawrence \& Lorsch, 1967). Burgers et al. (2009) found that structural differentiation has a positive effect on corporate venturing. Deducing from the above definitions, structural differentiation is defined as the change of organisational systems and subsystem elements to meet the organisational needs for expansion, sustainability and survival.

\subsection{Organisational Learning Capability}

The idea of organisational learning capability appears to emphasise the significance of the encouraging elements for organisational learning or the organisational propensity to learn (Chiva, Alegre \& Lapiedra, 2007). The significance of the elements that encourage organisational learning has generally been outlined by the learning organisation literature, which creates prescriptive models to become a learning organisation. Organisational learning capability is defined as the 
organisational and managerial characteristics, practices, skills and factors that facilitate the organisational learning processes (e.g. generating, acquiring, disseminating and integrating information/knowledge) and, allows an organisation to learn (Thomas, Dorrington, Costa, Loudon, Francis, \& Fisher, 2017). "Organisational learning capability is a collection of resources and/or tangible and intangible skills for which it is necessary to also use competitive advantages" (Alikhani, Fazlollahtabar \& Mahdavi, 2013, p.210). Moreover, organisational learning capability is an indication of creation capacity and a combination of thoughts in a compelling route in contact with different organisational borders and through special managerial methods strategies and developments (Rashidi, Habibi, \& Farsani, 2010; Alikhani et al., 2013).

\subsection{Corporate Venturing}

Corporate venturing is a system for business improvement (Husted \& Vintergaard, 2004). Recent literature has explored corporate venturing, Hunt, Townsend, Asgari and Lerner (2019) looked at how to reduce failures in corporate venturing while Lin and Chen (2019) investigated exploitation and ethical practices in corporate venturing. The present study, however, investigates the effect of corporate venturing and business growth. Narayanan et al. (2009) assert that corporate venturing concentrates on the different stages and processes related with constructing new enterprises and incorporating them into the company's general business portfolio. Other authors describe corporate venturing as a procedure of constructing new enterprises (Guth \& Ginsberg, 1990; Sharma \& Chrisman, 1999), whereas, Covin and Miles (2007) state that corporate venturing includes enterprising activities in which established organisations put resources in and/or construct new organisations. Due to high-cost failures, firms are searching for innovative ways to engage in corporate venturing (Hunt et al., 2019), as this would result in firms realising the full potential of corporate entrepreneurship. Corporate venturing is proposed to pursue a system of disconnected current activities, to assume the structure of a free unit and to include a procedure of gathering and arranging novel resources (Ellis \& Taylor, 1987; Sharma \& Chrisman, 1999). Organisations that employ structural differentiation mechanisms are more likely to succeed in their corporate venturing efforts (Burgers et al., 2009; Terjesen, Patel, \& Sanders, 2012). For this study, corporate venturing is defined as the organisational process of exploiting resources while exploring opportunities for new businesses.

\subsection{Business Growth}

Business growth is a concept that has been researched by scholars from widely varying perspectives. For example, Ye, Xiao and Zhou (2019) assessed business growth in the hospitality sector through measuring financial performance of small accommodation business while Agarwal, Qian, Yeung and Zou (2019), investigated the relationship between mobile wallet and entrepreneurial growth. The current research, however, focuses on how business growth is impacted by structural differentiation, organisational learning capability and corporate venturing. Understanding the ways in which customers make decisions is necessary for business (Ndlela \& Chuchu, 2016). This probably holds true for the growth of those businesses. Regardless of whether an enterprise is a start-up or a global multinational, almost every organisation has growth in its plans (Schwab et al., 2017). Business growth is a multi-faceted phenomenon that is ordinarily related with enterprise survival, accomplishment of enterprise objectives and success, or an increase in operations (Phillips, Moos \& Nieman, 2014). Growth determinants of small businesses can be classified in many factors: individual, organisational, and environmental, the factor of 
organisational resources, the competence of the company, organisational culture, and structure (Sarwoko \& Frisdiantara, 2016). Businesses can grow through diverse individuals joining for a common cause, a process known as integration (Hanks, 2019). This was an alternative view from structural differentiation proposed by Hanks (2019). Maziriri and Mapuranga (2018) describe business growth as the very essence of entrepreneurship. The growth of SMEs is determined by the owner/manager characteristics and personal approach, and how the strategy is taken by the managerial approach (Sarwoko \& Frisdiantara, 2016). Additionally, Maziriri and Mapuranga (2018) maintain that although several studies have analysed the elements of business growth, each factor was analysed separately, which only focused on personal features, organisational factors, as well as strategies. Maziriri and Mapuranga (2018) further concluded that the environment is a factor that also influences the growth of SMEs because growth is uncertain, due to environmental conditions such as competitive conditions and changing market dynamics. In the following section, the proposed conceptual model for the research is presented.

\section{CONCEPTUAL MODEL}

Based on a synthesis of the converging literature related to the research variables, a conceptual model was proposed to guide the empirical study as shown in Figure 1.

Figure 1: Conceptual Model

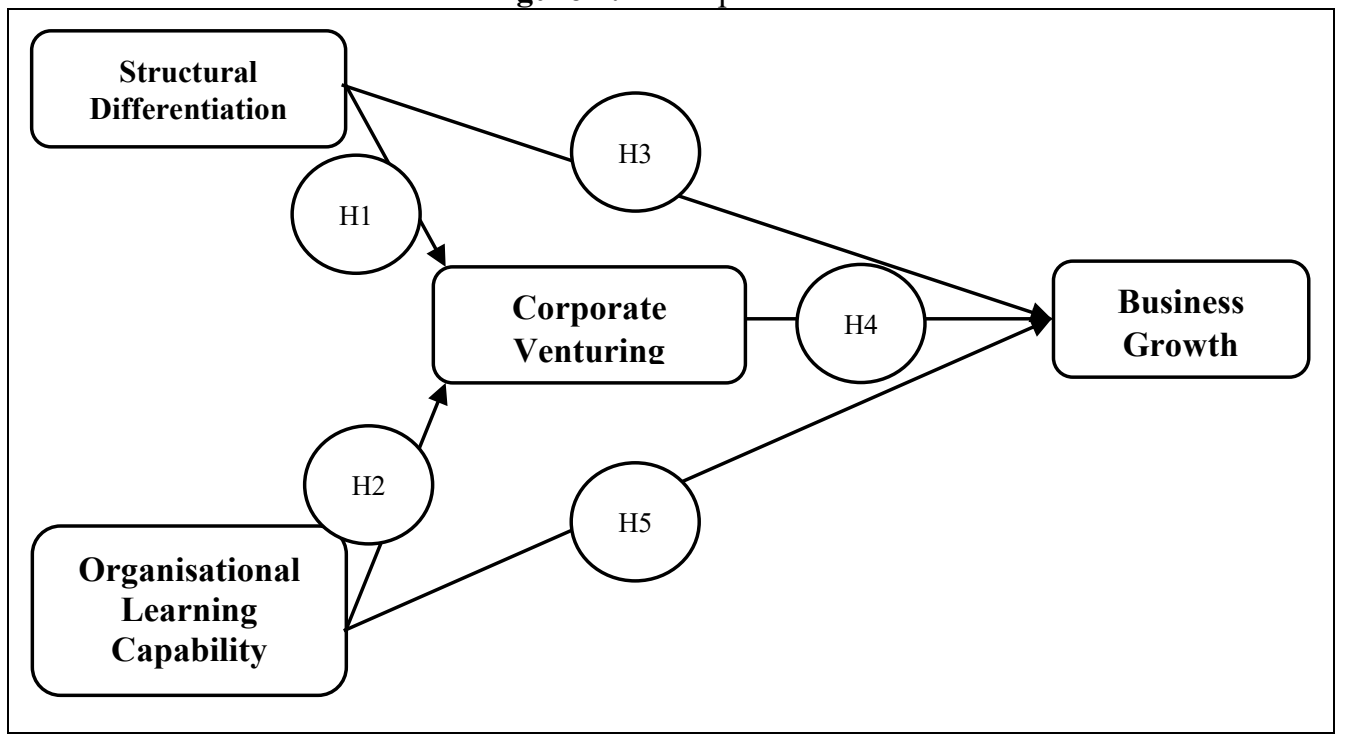

The literature throws the spotlight upon several validated works, thereby presenting the prospects to test a series of hypotheses in this work. This study used hypotheses to state specific relationships between variables in such a way that the relationships can be empirically tested. In addition, the hypotheses were used to validate the theory used in the research and to allow logical analysis of relationships of variables to deduce the interplay of those variables. Based on scientific evidence regarding structural differentiation, corporate venturing, organisational learning capability, 
corporate venturing and business growth and in light of the underlying theory, the study developed five hypothesis statements.

H1: Structural differentiation has a positive impact on the corporate venturing of SMEs.

\subsection{Organisational Learning Capability and Corporate Venturing}

The ability of an organisation to engage in venturing through the exploration and identification of opportunities is influenced by its organisational learning processes (Lichtenstein \& Lumpkin, 2002). Through continuous learning, organisations are able to acquire and transform information in new ways, resulting in the identification of opportunities (Corbett, 2005). Moreover, another closely related study which focused on the nexus between organisational learning capability and corporate venturing is the one conducted by Ahmed, Sabir, Sohail and Mumtaz (2011); their study's results indicated a positive and significant relationship between variables. Following on from this discourse, the following hypotheses are proposed for the study:

H2: Organisational learning capability has a positive impact on the corporate venturing of SMES.

\section{2. $\quad$ Structural Differentiation and Business Growth}

The structure of an organisation has a positive impact on the performance and growth of the small organisation (Keats \& Hitt, 1988). A growth orientated strategic intent of an organisation follows the structural configuration of the organisation (Maduenyi, Oke, Fadeyi \& Ajagbe, 2015; Miller, 1987). According to Michael Porter's generic competitive strategies, the differentiation strategy is utilised to enhance competitive advantage as well as growth of the firm. As far as business growth is concerned, structural differentiation has been viewed as an antecedent of ambidexterity (the ability to handle conflicting business tasks) (Jansen, Tempelaar, Van Den Bosch, \& Volberda, 2009). Furthermore, Jansen et al. (2009) postulated that structural differentiation would lead to ambidexterity through rewarding senior managers and connectedness throughout the organisation. Therefore, it is against this background that the following hypothesis has been formulated for the study:

H3: Structural differentiation has a positive impact on the business growth of SMEs.

\subsection{Corporate Venturing and Business Growth}

Innovation and the constant search of new business opportunities is vital for growth at the firm level (Kerr, 2016). Corporate venturing gives way to entrepreneurial behaviour to generate business model innovation (Futterer, Schmidt \& Heidenreich, 2018). The success of corporate ventures is dependent on an organisation's ability to anticipate the type of offerings that would appeal to its target market as well as the ability to adjust its value propositions as the venture develops (Covin, Garrett, Kuratko \& Shepherd, 2015). Furthermore, Covin et al. (2015) posit that corporate ventures grow through leveraging the parent corporation's knowledge. Rajakumar and Banumathi (2017) state that corporate venturing can play a very important role in achieving higher levels of corporate performance, organisational growth and profitability. In a similar vein, Scholtz (2009) notes that firms engage in corporate venturing to grow the firm's existing business, by 
forming part of a firm's business development strategy. Corporate venture investments are an established means for organisations to access radical innovation (Hussinger, Dick \& Czarnitzki, 2018). Based on the aforementioned literature, the following hypothesis is proposed.

H4: Corporate venturing has a positive impact on the business growth of SMEs.

\subsection{Organisational Learning Capability and Business Growth}

Organisational learning by organisations enhances their ability to be more innovative and grow within the market (Martínez-Costa, Jiménez-Jiménez \& Dine Rabeh, 2019). It was postulated by Saadat and Saadat (2016) that organisational learning was an antecedent of organisational success. Organisational learning is believed to have an impact on performance (Ali, Peters, Khan, Ali \& Saif, 2019). This relationship is, however, indirect, as it is mediated by the dynamic and substantive capabilities possessed by a firm (Ali et al., 2019). Altinay Madanoglu, De Vita, Arasli and Ekinci (2016) confirmed a positive relationship between organisational learning capability and SME growth. Organisational learning as a strategic tool for businesses has been responsible for providing competitive advantage and stabilising organisational success (Saadat \& Saadat, 2016). Based on the aforementioned literature, the following hypothesis is proposed.

H5: Organisational learning capability has a positive impact on the business growth of SMEs

\section{METHODOLOGY}

\subsection{Research Design}

The study utilised a quantitative research design, adopting the survey method. The design was deemed suitable to solicit the required information relating to structural differentiation, organisational learning capability, corporate venturing and business growth. In addition, the approach enabled the examination of the causal relationships with the constructs used in the study. The sample used for the study was drawn from the Small Enterprise, Emfuleni Municipality in the Vaal Triangle region of the Gauteng Province. The data was subsequently collected from SMEs operating in that province.

\subsection{Data Collection, Questionnaire Design and Analysis}

The data collection resulted in 151 usable responses obtained from managers/ owners of SMEs across the Emfuleni Municipality, Gauteng province in South Africa. The questions used to extract information from the participants were loosely based on previous studies and appropriate adaptations were made to fit the current research context and purpose. Structural differentiation was measured with a six-item scale adapted from Burgers, Jansen, Van Den Bosch and Volberda (2009). A fifteen-item scale was adapted from Gomez et al. (2005) to measure organisational learning capability. Corporate venturing was measured using a four-item scale adapted from Hooi (2014). Moreover, business growth was measured using a four-item scale adapted from Lotz and van der Merwe (2013). After the data was collected, it was processed through Smart PLS software for structural equation modelling. In addition, descriptive statistics were conducted to illustrate the sample profile. 


\section{SAMPLE COMPOSITION}

Table 1 depicts the participants. The respondents were requested to report their demographic data, including gender, age, marital status and the type of SME. The respondents were mainly female and represented $57 \%$ of the sample. The average age of the respondents is younger than or at least 30 years at $54 \%$.

Table 1: Sample demographic characteristics

\begin{tabular}{lcc}
\hline \multicolumn{1}{c}{ Characteristics } & Frequency & Percentage \\
\hline Gender & 64 & $42 \%$ \\
Male & 87 & $58 \%$ \\
Female & 151 & $100 \%$ \\
Total & & \\
\hline Age & 82 & $54 \%$ \\
$\leq 30$ & 51 & $34 \%$ \\
$31-60$ & 18 & $12 \%$ \\
$\geq 60$ & 151 & $100 \%$ \\
Total & & \\
SME Type & 90 & $60 \%$ \\
Retail/ Sales & 41 & $27 \%$ \\
Services & 20 & $13 \%$ \\
Manufacturing & 151 & $100 \%$ \\
Total & & \\
\hline Size of SME & 60 & $40 \%$ \\
$<10$ & 68 & $45 \%$ \\
$10<50$ & 23 & $15 \%$ \\
50 to 100 & 151 & $100 \%$ \\
Total & & \\
\hline Years in operation & 98 & $65 \%$ \\
$1-5$ & 53 & $35 \%$ \\
More than 5 & 151 & $100 \%$ \\
Total & & \\
\hline \hline
\end{tabular}

Most managers of SMEs stated that they had been in operation for only one to five years. This group represented $65 \%$ of the entire sample. SME managers with more than five years in operation accounted for only $35 \%$ of the sample. As for the type of SME, more than half were in retail/sales as indicated by $60 \%$ while services-based SMEs represented $27 \%$ of the sample. SMEs specialising in manufacturing were the least represented, only accounting for $13 \%$ of the sample. SMEs that had a staff complement of 10 to 49 employees accounted for $45 \%$ of the sample while those that had less than 10 employees accounted for $40 \%$ of the sample. Larger SMEs, those with 50 to 100 staff, only accounted for $15 \%$ of the sample. 


\subsection{Reliability Analysis}

The researchers checked the measurements' reliability and validity. Reliability was mainly checked using the composite reliability (CR) and Cronbach's alpha values. To ensure convergent validity, the researchers checked if items loaded on their respective (a priori) constructs with loadings greater than 0.5 , while discriminant validity was checked by average variance extracted (AVE) value and ensuring that there were no significant inter-research variable cross-loadings (Chin 1998). The statistical measures of accuracy tests, as shown in Table 2, specify the different measures that were used to assess the reliability and validity of the constructs for the study.

Table 2: Accuracy Analysis Statistics

\begin{tabular}{|c|c|c|c|c|c|c|c|c|}
\hline \multicolumn{2}{|c|}{$\begin{array}{l}\text { Research } \\
\text { constructs }\end{array}$} & \multicolumn{2}{|c|}{ Scale item } & \multicolumn{2}{|c|}{ Cronbach's test } & \multirow{2}{*}{$\begin{array}{c}\text { CR } \\
\text { Value }\end{array}$} & \multirow{2}{*}{$\begin{array}{c}\text { AVE } \\
\text { Value }\end{array}$} & \multirow{2}{*}{$\begin{array}{c}\text { Factor } \\
\text { Loadings }\end{array}$} \\
\hline $\begin{array}{l}\text { PLS } \\
\text { code }\end{array}$ & $\begin{array}{l}\text { PLS } \\
\text { code } \\
\text { item }\end{array}$ & Mean & SD & $\begin{array}{l}\text { Item- } \\
\text { total }\end{array}$ & $\begin{array}{c}\alpha \\
\text { value }\end{array}$ & & & \\
\hline \multirow{6}{*}{ SD } & SD1 & 3.52 & 0.889 & 0.592 & 0.887 & 0.915 & 0.643 & 0.740 \\
\hline & SD2 & 3.64 & 0.819 & 0.558 & & & & 0.844 \\
\hline & SD3 & 3.58 & 0.841 & 0.574 & & & & 0.865 \\
\hline & SD4 & 3.46 & 0.964 & 0.557 & & & & 0.694 \\
\hline & SD5 & 3.39 & 1.104 & 0.516 & & & & 0.785 \\
\hline & SD6 & 3.20 & 0.962 & 0.544 & & & & 0.866 \\
\hline \multirow{14}{*}{ OLC } & OLC1 & 3.52 & 1.082 & 0.506 & 0.922 & 0.932 & 0.480 & 0.586 \\
\hline & OLC2 & 3.64 & 1.141 & 0.698 & & & & 0.737 \\
\hline & OLC3 & 3.58 & 0.870 & 0.623 & & & & 0.733 \\
\hline & OLC4 & 3.46 & 0.995 & 0.647 & & & & 0.747 \\
\hline & OLC5 & 3.39 & 0.982 & 0.694 & & & & 0.768 \\
\hline & OLC6 & 3.20 & 0.819 & 0.662 & & & & 0.696 \\
\hline & OLC7 & 3.22 & 0.901 & 0.664 & & & & 0.586 \\
\hline & OLC8 & 3.10 & 0.828 & 0.760 & & & & 0.708 \\
\hline & OLC9 & 3.40 & 0.790 & 0.719 & & & & 0.682 \\
\hline & OLC10 & 3.51 & 0.761 & 0.748 & & & & 0.696 \\
\hline & OLC12 & 3.52 & 0.786 & 0.780 & & & & 0.573 \\
\hline & OLC13 & 3.58 & 0.783 & 0.715 & & & & 0.747 \\
\hline & OLC14 & 3.58 & 0.762 & 0.711 & & & & 0.767 \\
\hline & OLC15 & 3.56 & 0.754 & 0.756 & & & & 0.695 \\
\hline \multirow[t]{4}{*}{$\mathrm{CV}$} & CV1 & 3.51 & 0.756 & 0.549 & 0.823 & 0.883 & 0.656 & 0.703 \\
\hline & $\mathrm{CV} 2$ & 3.40 & 0.829 & 0.536 & & & & 0.871 \\
\hline & CV3 & 3.47 & 0.839 & 0.566 & & & & 0.838 \\
\hline & $\mathrm{CV} 4$ & 3.52 & 0.806 & 0.515 & & & & 0.818 \\
\hline
\end{tabular}




\begin{tabular}{|c|c|c|c|c|c|c|c|c|}
\hline \multicolumn{2}{|c|}{$\begin{array}{l}\text { Research } \\
\text { constructs }\end{array}$} & \multicolumn{2}{|c|}{ Scale item } & \multicolumn{2}{|c|}{ Cronbach's test } & \multirow{2}{*}{$\begin{array}{c}\text { CR } \\
\text { Value }\end{array}$} & \multirow{2}{*}{$\begin{array}{c}\text { AVE } \\
\text { Value }\end{array}$} & \multirow{2}{*}{$\begin{array}{c}\text { Factor } \\
\text { Loadings }\end{array}$} \\
\hline $\begin{array}{l}\text { PLS } \\
\text { code }\end{array}$ & $\begin{array}{l}\text { PLS } \\
\text { code } \\
\text { item }\end{array}$ & Mean & SD & $\begin{array}{l}\text { Item- } \\
\text { total }\end{array}$ & $\begin{array}{c}\alpha \\
\text { value }\end{array}$ & & & \\
\hline \multirow{4}{*}{ BG } & BG 1 & 3.70 & 0.809 & 0.794 & \multirow{4}{*}{0.747} & \multirow{4}{*}{0.840} & \multirow{4}{*}{0.569} & 0.763 \\
\hline & BG 2 & 3.71 & 0.762 & 0.738 & & & & 0.819 \\
\hline & BG 3 & 3.63 & 0.775 & 0.757 & & & & 0.722 \\
\hline & BG 4 & 3.51 & 0.740 & 0.866 & & & & 0.708 \\
\hline
\end{tabular}

$\alpha$, alpha; CR, composite reliability; AVE, average variance reliability; SD, Structural differentiation; OLC, Organisational learning capability; CV, Corporate venturing; BG, Business Growth.

In this study, structural equation modelling (SEM) was employed, using partial least squares (PLS) analysis to assess measurement and the structural model for reflecting constructs and testing the proposed research arguments (Rezaei, Shahijan, Valaei, Rahimi \& Ismail, 2018). Factor loadings (standardised regression weights) are required to be above 0.5 to ensure that there is convergent validity, and in the instance that certain factor loadings are below this threshold, they should be removed. Since the factor loading scores of all the variables were above the acceptable threshold, there were no items removed during the statistical analysis process. As can be seen (Table 2), all items have loadings greater than 0.6 (Nunnally \& Bernstein 1994), indicating that they explain at least $60 \%$ of what they expected to measure (convergent validity). The lowest AVE value is 0.578 , which exceeds the recommended 0.5 (Fornell \& Larcker, 1981) - an indication of the existence of discriminant validity. The $\mathrm{CR}$ values illustrated in Table 2 indicate that all the $\mathrm{CR}$ values meet the minimum threshold of 0.6 as they range from $\mathrm{CR}$ values of 0.815 to 0.935 .

According to Yang and Lai (2010), when conducting reliability analysis, it is recommended that the $\mathrm{CR}$ value exceed a value of 0.7 , which was clearly achieved, as demonstrated in Table 2 . Again, based on the values presented in Table 2, it can be concluded that all the measurement instruments are reliable on the basis that the Cronbach alpha values are required to be above or equal to 0.6 and, in this case, all the values substantially exceeded this threshold. The values ranged from 0.764 to 0.936 and thus the measurement instruments are deemed reliable (Morar, Venter \& Chuchu, 2015). According to the accuracy table presented above (Table 2), the mean value for all the constructs ranges between 3 and 4, indicating that most of the respondents had either a neutral standpoint ( 3 on the Likert scale) or they agreed ( 4 on the Likert scale) with the statements provided. The standard deviation specifies the extent to which the respondents deviated from the mean. Preferably, this value should be less than 1 but is recommended to at least encompass a value of less than 2 to ensure that there is no issue of outliers (Drost, 2011); however, as seen in the accuracy in Table 2, all the remaining constructs had standard deviation values that were substantially below 2 . The item to total statistics for each item analysed through SPSS are required to be above 0.5 to assess convergent validity (Morar et al. 2015). According to the accuracy table (Table 2), the majority of the instruments met the threshold of 0.5 . 
Table 3: Inter-construct Correlation Matrix

\begin{tabular}{lcccc}
\hline \hline $\begin{array}{l}\text { Research } \\
\text { construct }\end{array}$ & BG & CV & OLC & SD \\
\hline BG & 1.000 & - & - & - \\
CV & 0.639 & 1.000 & - & - \\
OLC & 0.618 & 0.655 & 1.000 & - \\
SD & 0.507 & 0.699 & 0.681 & 1.000 \\
\hline \hline
\end{tabular}

Key: SD, Structural differentiation; OLC, Organisational learning capability; CV, Corporate venturing; BG, Business Growth

The inter-construct correlation matrix is used to assess the validity of measurement instruments, specifically discriminant validity. Correlations among constructs were evaluated to see if they were lower than 1 . The higher the correlation between variables, the lower the validity of those variables. The inter-construct values are required to be below 0.6 and in some cases, below 0.85 to indicate discriminant validity. According to Table 3, the highest correlation value was 0.699 and the lowest correlation value was 0.507 .

Figure 2: Structural model

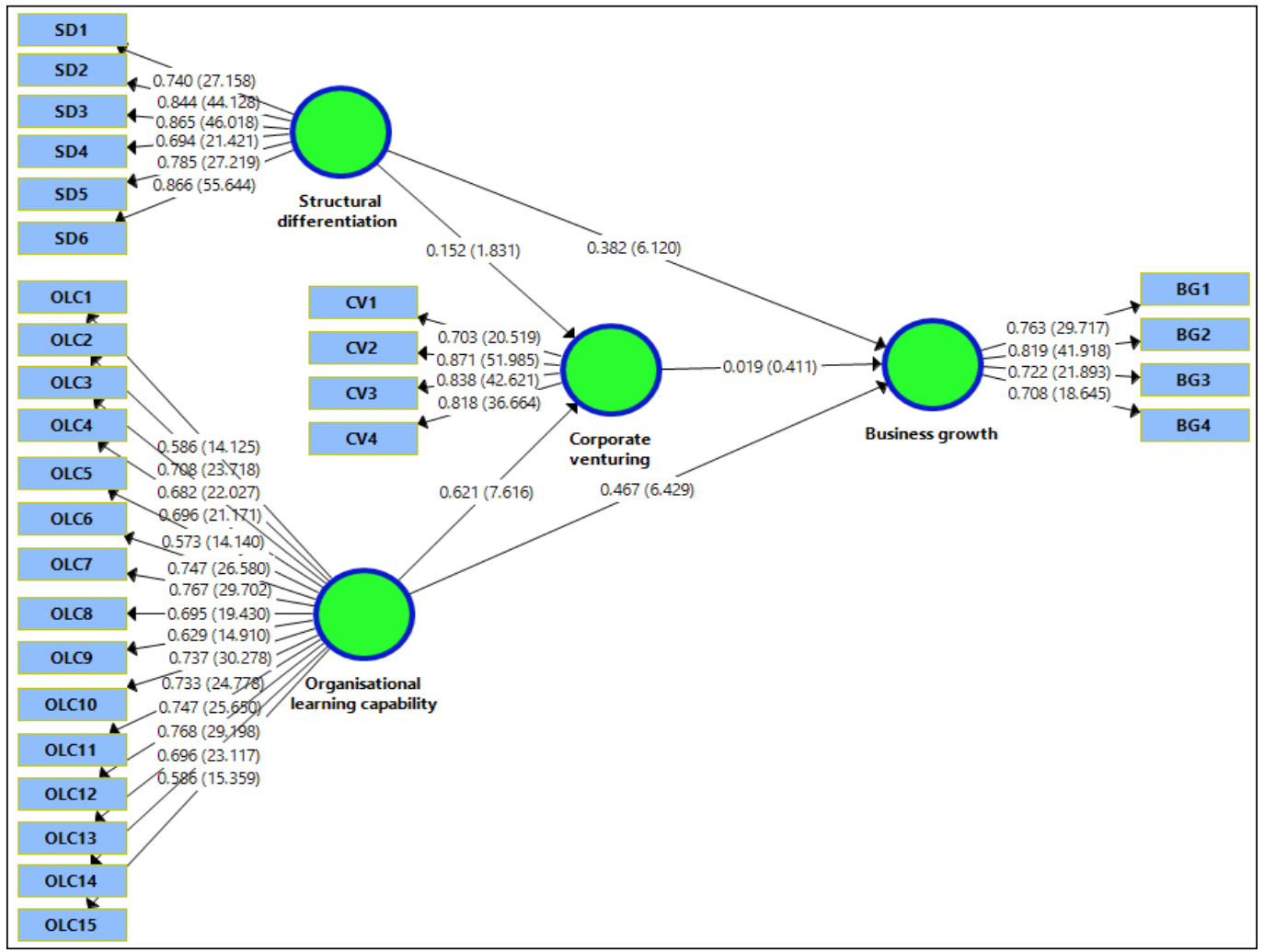

In figure 2 , it can be observed that all proposed hypotheses are supported. Organisational learning capability was seen to have a significantly stronger impact on corporate venturing as compared to 
structural differentiation. It was, however, interesting to note that based on the findings, corporate venturing had a fairly weak impact on business growth. In this study, testing of the hypothesis was determined by the path coefficient values as well as the t-values for the structural model obtained from the bootstrapping algorithm. According to Beneke and Blampied (2012), t-values indicate whether or not a significant relationship exists between variables within the model and path coefficients demonstrate the strength of the relationships in the model. Two tailed t-tests were conducted at the five percent significance level.

\subsection{Outcome of Hypothesis 1: Structural differentiation has a positive impact on the corporatee venturing of SMEs}

In this study, this hypothesis was supported. It can be observed in Figure 2 that structural differentiation exerted a positive impact $(\beta=0.152)$ and was statistically insignificant $(\mathrm{t}=1.831)$ in predicting corporate venturing. This result suggests that structural differentiation positively influences corporate venturing of SMEs, but the significance level is weak. In support of the findings, structural differentiation is believed to form "pragmatic boundaries" (Carlile, 2004) that protect corporate venturing activities from predominant managerial insights and idleness present in the parent's mainstream activities (Benner \& Tushman, 2003; Gilbert, 2005). Additionally, structural differentiation gives corporate ventures a sense of opportunity and responsibility over their activities. Such spatial separation prompts higher innovativeness (Amabile, Conti, Coon, Lazenby \& Herron, 1996) and permits adaptation to local demands (Burgers et al., 2009). Hence, structural differentiation effectiveness contributes in facilitating corporate venturing. Moreover, structural differentiation allows corporate ventures to be relatively independent of the other organisational units with a limited need for knowledge exchange and combinations thereof (Burgers et al., 2009). The authors further emphasised that only certain aspects of structural differentiation contribute to the pursuit of corporate venturing in established organisations (Burgers et al., 2009).

\subsection{Outcome of Hypothesis 2: Organisational learning capability has a positive impact on the corporate venturing of SMEs}

In this study, this hypothesis was supported. It can be observed in Figure 2 that organisational learning capability exerted a positive impact $(\beta=0.621)$ and was statistically significant $(\mathrm{t}=7.616)$ in predicting corporate venturing. This result implies that organisational learning capability directly influences corporate venturing in a positive and significant fashion. Therefore, it can be noted that the more a company capitalises on its organisational learning capability, it ultimately leads to an SME's ability to engage in corporate venturing. The results of this study are consistent with literature. Organisational learning capabilities are referred to as the key viable solutions through corporate venturing in response to an unstable and turbulent business environment (Tohidi \& Mandegari, 2012). Furthermore, organisations that put resources into organisational learning capabilities are increasingly effective and enduring. One of the primary purposes behind the developing significance of the organisational learning capabilities in previous years is the requirement for innovation and survival in the evolving environment through corporate ventures (Tohidi \& Mandegari, 2012). Additionally, Ulrich, Von Glinow, and Jick (1993) also considered organisational learning capabilities as the capacity of managers in an organisation for further the production and combination of important and effective ideas which might prompt the creation of corporate ventures (Alikhani, Fazlollahtabar \& Mahdavi, 2013). 


\subsection{Outcome of Hypothesis 3: Structural differentiation has a positive impact on the business growth of SMEs}

Hypothesis 3 posited a positive association between structural differentiation and business growth. Consistent with Hypothesis 1 and 2, results indicated that higher levels of structural differentiation will lead to higher levels of business growth $(\beta=0.382 ; \mathrm{t}=6.120)$. Therefore, H3 is accepted since the relationship between structural differentiation and business growth was positive and significant. Thus, it can be noted that if the management of SMEs capitalises in engaging in structural differentiation, this would ultimately lead to increasing the business growth of SMEs. These results are in line with a study conducted by Jansen et al. (2009), which revealed that structural differentiation establishes differences across organisational units in terms of mindsets, time orientations, functions, and product/market domains with the aim of pursuing growth. Cullen et al. (1986) assert that structural differentiation should be interpreted for both declining and growing organisations.

\subsection{Outcome of Hypothesis 4: Corporate venturing has a positive impact on the business growth of SMEs}

The fourth hypothesis proposed that corporate venturing has a positive impact on business growth of SMEs. This hypothesis was reinforced in this study. Figure 2 indicates that the relationship between corporate venturing and business growth is positive $(\beta=0.019)$. However, its significance level is weak as indicated by $(\mathrm{t}=0.411)$. Overall, this result signifies that corporate venturing is related positively and meaningfully to business growth. Thus, higher levels of corporate venturing will lead to increasing the business growth of SMEs. In addition, the results of this study are also in line with the works of Wiklund, Patzelt and Shepherd (2009) who proposed that corporate venturing directly and/or indirectly impacts the growth of small businesses. Corporate venturing can contribute fundamentally to the advancement of an organisation's corporate plan by building new capabilities and industries that empower re-establishment, encourage strategic change and improve an organisation's revenues and growth, both in local and worldwide markets (Ireland, Hitt, Camp \& Sexton, 2001; Zahra \& Hayton, 2008; Narayanan, Yang \& Zahra, 2009). Organisations can utilise a wide range of techniques for overseeing new knowledge for novel innovations; though, corporate venturing differs from normal business practices by encouraging growth through acquisition (Albrinck et. al., 2000; McGrath \& MacMillan, 2000; Vintergaard, 2006).

\subsection{Outcome of Hypothesis 5: Organisational learning capability has a positive impact on the business growth of SMEs}

Moreover, the fifth hypothesis proposed that organisational learning capability has a positive impact on business growth. This hypothesis was reinforced in this study. Figure 2 indicates that organisational learning capability and business growth were supported. Organisational learning capability exerted a positive impact $(\beta=0.467)$ on business growth $(t=6.429)$. This result signifies that organisational learning capability is related positively and meaningfully to business growth. Thus, higher levels of organisational learning capability will lead to higher levels of business growth. The findings are backed by the study of Tohidi and Mandegari (2012) that the organisational learning capabilities has a basic influence in the improvement and advancement of organisations and builds the capability of growth. Organisational learning capacity has been viewed as a key marker of an organisation's effectives and potential to innovate and grow (Jerez- 
Gómez, Céspedes-Lorente, \& Valle-Cabrera, 2005; Alegre \& Chiva, 2009). Tran (2008) inferred that a few organisations are progressively creative on the grounds that they consider learning. One of the fundamental purposes behind the developing significance of the organisational learning capabilities is the necessity for innovation and growth in the evolving environment (Alegre \& Chiva, 2008; Tohidi \& Mandegari, 2012).

\section{IMPLICATIONS FROM THE STUDY}

The implication of this finding is that for corporate venturing to be successful, there is a need for more allocation of resources toward organisational learning capability. This applies to researchers (from an academic point of view) who need to investigate organisational learning capabilities further and practitioners who need to provide resources that support organisational learning within SMEs. In addition, policy makers need to provide conducive environments that encourage corporate venturing as the results suggest that they influence business growth, regardless of how small this influence might be. Engaging in organisational learning capability will likely encourage business growth in the future. Structural differentiation is observed as having a positive relationship with organisational growth. This implies that SME managers with the ability to have separate functions that aim to fulfil different business objectives have to potential to grow their businesses. Lastly, the present study offers implications for policy makers who have been developing SMEs business policies that enhance corporate venturing and business growth. Policies which exist in various small and medium enterprises can be modified to incorporate venturing and business growth. Thus, the results which have been obtained from this study may be used to generate new policies and revision of the existing policies.

\section{LIMITATIONS AND FUTURE RESEARCH SUGGESTIONS}

Although the present study offers valuable insights pertaining to the impact of structural differentiation and organisational learning capability on corporate venturing and business growth of small and medium enterprises in Johannesburg South Africa, it is prone to limitations that offer avenues for future research. The results of this study are based on a sample of 150 respondents which is not a large sample and the study was conducted only in Johannesburg and findings may not be generalised to the whole of South Africa. Therefore, future studies, should take into consideration other areas of South Africa. This will eventually offer more insight and accurate research findings into the understanding of the impact of structural differentiation and organisational learning capability on corporate venturing and business growth of small and medium enterprises in Johannesburg South Africa. Furthermore, the study only made use of a quantitative research approach. Future research may consider using a mixed-method approach that includes both a qualitative and quantitative research design, where a quantitative design technique could be more reliable and objective because of the use of statistics to generalise the findings. 


\section{REFERENCES}

Ahmed, B., Sabir, H. M., Sohail, N., \& Mumtaz, R. (2011). Does corporate entrepreneurship matter for organisational learning capability? A study on textile sector in Pakistan. European Journal of Business and Management, 3(7), 53-58.

Alegre, J., \& Chiva, R. (2009). Entrepreneurial orientation, innovation and firm performance: The importance of organizational learning capability. In Unpublished paper presented at the International Conference on Organizational Learning, Knowledge and Capabilities $(O L K C)$, Amsterdam, Netherlands.

Ali, S., Peters, L. D., Khan, I. U., Ali, W., \& Saif, N. (2019). Organisational learning and hotel performance: The role of capabilities' hierarchy. International Journal of Hospitality Management. 85(1), 1-12.

Alikhani, M., Fazlollahtabar, H., \& Mahdavi, I. (2013). Clustering organisational learning capability indices for knowledge sharing in different segments of the Firm. International Journal of Management, Knowledge and Learning, 2(2), 209-225.

Altinay, L., Madanoglu, M., De Vita, G., Arasli, H, \& Ekinci, Y. (2016). The interface between organisational learning capability, entrepreneurial orientation, and SME growth. Journal of Small Business Management, 54(3), 871-891.

Amabile, T. M., Conti, R., Coon, H., Lazenby, J., \& Herron, M. (1996). Assessing the work environment for creativity. Academy of Management Journal, 39(5), 1154-1184.

Arthur-Aidoo, B. M., Aigbavboa, C. O., \& Thwala, W. D. (2018). Exploratory factor analysis on drivers of firm's growth among construction SMEs in Ghana. African Journal of Science, Technology, Innovation and Development, 10(1), 20-27

Backholm, A. (1999). Corporate venturing: An overview. Espoo, Finland: Helsinki University of Technology.

Barney, J. (1991). Firm resources and sustained competitive advantage. Journal of management, 17(1), 99-120.

Barney, J., Wright, M., \& Ketchen Jr, D. J. (2001). The resource-based view of the firm: Ten years after 1991. Journal of Management, 27(6), 625-641.

Beneke, J., \& Blampied, S., (2012). Driving consumer perceptions through Facebook: An investigation into empowering brands in the 21st century, in J.M.M. Van Den Berg (ed.), Conference proceedings of the 24th annual conference of SAIMS - 2012, Stellenbosch University, Stellenbosch, September 09-11, 2012. (pp. 47-61). South Africa

Benner, M. J., \& Tushman, M. L. (2003). Exploitation, exploration, and process management: The productivity dilemma revisited. Academy of Management Review, 28(2), 238-2560.

Brink, A., Cant, M., \& Ligthelm, A. (2003). Problems experienced by small businesses in South Africa. In 16th Annual Conference of Small Enterprise Association of Australia and New Zealand, 28, 1-20.

Burgers, J. H., Jansen, J. J., Van den Bosch, F. A., \& Volberda, H. W. (2009). Structural differentiation and corporate venturing: The moderating role of formal and informal integration mechanisms. Journal of business venturing, 24(3), 206-220.

Burgers, J. H., \& Covin, J.G. (2016). The contingent effects of differentiation and integration on corporate entrepreneurship. Strategic Management Journal, 37(3), 521-540.

Cant, M. C., \& Wiid, J. A. (2013). Establishing the challenges affecting South African SMEs. The International Business \& Economics Research Journal (Online), 12(6), 707-716.

Carlile, P. R. (2004). Transferring, translating, and transforming: An integrative framework for managing knowledge across boundaries. Organisation Science 15(5), 555-568. 
Chiva, R., Alegre, J., \& Lapiedra, R. (2007). Measuring organisational learning capability among the workforce. International Journal of Manpower, 28(3/4), 224-242.

Corbett, A. C. (2005). Experiential learning within the process of opportunity identification and exploitation. Entrepreneurship Theory and Practice, 29(4), 473-491.

Covin, J. G., \& Miles, M. P. (2007). Strategic use of corporate venturing. Entrepreneurship Theory and Practice, 31(2), 183-207.

Covin, J. G., Garrett Jr, R. P., Kuratko, D. F., \& Shepherd, D. A. (2015). Value proposition evolution and the performance of internal corporate ventures. Journal of Business Venturing, 30(5), 749-774.

Cullen, J. B., Anderson, K. S. \& Baker, D. D. (1986). Blau's theory of structural differentiation revisited: A theory of structural change or scale? Academy of Management Journal, 29(2), 203-229.

Desta, N. T. (2015). Networking as a growth initiative for small and medium enterprises in South Africa (Doctoral dissertation, University of the Free State, Bloemfontein, South Africa). Retrieved from https://scholar.ufs.ac.za/handle/11660/2287

Drost, E. A. (2011). Validity and reliability in social science research. Education Research and perspectives, $38(1), 105-124$

Ellis, R. J., \& Taylor, N. T. (1987). Specifying entrepreneurship. Frontiers of Entrepreneurship Research, 00(0), 527-541.

Farrel, J. P. (1969). The structural differentiation of developing educational systems: A Latin American. Comparison Comparative Education Review, 13(3), 294-311.

Feeney, L. S., \& Riding, A. L. (1997). Business owner's fundamental trade off. Finance and the vicious circle of growth and control. Canadian Business Owners, November. 00(0)

Fida, B. A. (2008). The role of small and medium enterprises (SMEs) in economic development. enterprise development, The free library. Retrieved from https://www.thevillager.com.na/articles/1973/The-Importance-of-Small--MediumEnterprises--SMEs--in-the-economy/

Fornell, C., \& Larcker, D. F. (1981). Evaluating structural equation models with unobservable variables and measurement error. Journal of marketing research, 18(1), 39-50.

Futterer, F., Schmidt, J., \& Heidenreich, S. (2018). Effectuation or causation as the key to corporate venture success? Investigating effects of entrepreneurial behaviors on business model innovation and venture performance. Long Range Planning, 51(1), 64-81.

Gilbert, C. G. (2005). Unbundling the structure of inertia: Resource versus routine rigidity. Academy of Management Journal, 48(5), 741-763.

Gilbert, C. G. (2006). Change in the presence of residual fit: can competing frames coexist? Organisation Science, 17(1), 150-167.

Golden, B. R., \& Ma, H. (2003). Mutual forbearance: The role of intrafirm integration and rewards. Academy of Management Review, 28(3), 479-493.

Gomeza, P. (2005). Organisational learning capability: A proposal of measurement. Journal of Business Research, 58(6), 715-725.

Guth, W. D. \& Ginsberg, A. (1990). Guest editors' introduction: Corporate entrepreneurship. Strategic Management Journal, 11, 5-15.

Hanks (2019). What is differentiation \& integration in organization development? Retrieved from https://smallbusiness.chron.com/differentiation-integration-organization-development70838.html 
Hooi, L. W. (2014). HRM intensity, corporate entrepreneurship and organisational learning capability in SMEs: What is the relationship? In Proceedings of International Academic Conferences. International Institute of Social and Economic Sciences.

Hunt, R. A., Townsend, D. M., Asgari, E., \& Lerner, D. A. (2019). Bringing it all back home: Corporate venturing and renewal through spin-ins. Entrepreneurship Theory and Practice, 43(6), 1166-1193.

Husted, K., \& Vintergaard, C. (2004). Stimulating innovation through corporate venture bases. Journal of World Business, 39(3), 296-306.

Hussinger, K., Dick, J. M., \& Czarnitzki, D. (2018). Ownership concentration and innovativeness of corporate ventures. Research Policy, 47(2), 527-541.

Ireland, R. D., Hitt, M., Camp, S. M. \& Sexton, D. L. (2001). Integrating entrepreneurship and strategic management actions to create firm wealth. Academy of Management Executive, 15(1), 49-63.

Jansen, J. J., Tempelaar, M.P., Van den Bosch, F. A., \& Volberda, H. W. (2009). Structural differentiation and ambidexterity: The mediating role of integration mechanisms. Organisation science, 20(4), 797-811.

Jerez-Gómez, P., Céspedes-Lorente, J., \& Valle-Cabrera, R. (2005). Organisational learning and compensation strategies: evidence from the Spanish chemical industry, Human Resource Management, 44(3), 279-299.

Jyothibabu, C., \& Farooq, A. (2010). An integrated scale for measuring an organisational learning system. Learning Organisation, 17(4), 303-327.

Keats, B. W., \& Hitt, M. A. (1988). A causal model of linkages among environmental dimensions, macro organisational characteristics, and performance. Academy of Management Journal, 31(3), 570-598.

Keil, T. (2000). External corporate venturing: cognition, speed, and capability development. Espoo, Finland: Helsinki University of Technology.

Kerr, W. R. (2016): Innovation and business growth. Moving to the Innovation Frontier, 3, 41-53.

Kisaka, S. K., \& Mwewa, N. M. (2014). Effects of micro-credit, micro-savings and training on the growth of small and medium enterprises in Machakos County in Kenya. Research Journal of Finance and Accounting, 5(7), 43-49.

Kongolo, M. (2010). Job creation versus job shedding and the role of SMEs in economic development. African Journal of Business Management, 4(11), 2288-2295.

Lawrence, P. R., \& Lorsch, J. W. (1967). Differentiation and integration in complex organisations. Administration Science Quarterly, 12(1), 1-47.

Lichtenstein, B. B., \& Lumpkin, G. T. (2002). The role of organisational learning in the opportunity recognition process. In Entrepreneurial Learning (pp. 117-141). London: Routledge.

Maduenyi, S., Oke, A. O., Fadeyi, O., \& Ajagbe, A. M. (2015). Impact of organisational structure on organisational performance. International Conference of African Development Issues (CU-ICADI 2015) held on 11-13 ${ }^{\text {th }}$ May, 2015 (pp.354-358) Canaan Land, Nigeria.

Mafini, C., \& Loury-Okoumba, W. V. (2018). 'Extending green supply chain management activities to manufacturing small and medium enterprises in a developing economy'. South African Journal of Economic and Management Sciences, 21(1), 1-12.

Morar, A., Venter, M., \& Chuchu, T. (2015). To vote or not to vote: Marketing factors influencing the voting intention of university students in Johannesburg. Journal of Economics and Behavioral Studies, 7(6), 81-93. 
Martínez-Costa, M., Jiménez-Jiménez, D., \& Dine Rabeh, H. A. (2019). The effect of organisational learning on interorganisational collaborations in innovation: an empirical study in SMEs. Knowledge Management Research \& Practice, 17(2), 137-150.

Maziriri, E. T., \& Mapuranga, M. (2018). Modeling the nexus between entrepreneurial marketing dimensions and business growth among Small and Medium agro-processing enterprises in Zimbabwe. Journal of Agribusiness and Rural Development, 2(48), 153-163.

McGrath, R. G., \& MacMillan, I. (2000). The Entrepreneurial Mindset. Cambridge, MA.: Harvard Business School Press.

Miller, D. (1987). The structural and environmental correlates of business strategy. Strategic Management Journal, 8(1), 55-76.

Narayanan, V. K., Yang, Y., \& Zahra, S. A. (2009). Corporate venturing and value creation: A review and proposed framework. Research Policy, 38(1), 58-76.

Ndlela, T., \& Chuchu, T. (2016). Celebrity endorsement Advertising: Brand awareness, brand recall, brand loyalty as antecedence of South African young consumers' purchase behaviour. Journal of Economics and Behavioral Studies, 8(2), 79-90.

Niemann, I. (2006). Strategic integrated communication implementation: Towards a South African conceptual model (Doctoral Dissertation. Pretoria: University of Pretoria).

Nieman, G., Hough, J., \& Nieuwenhuizen, C. (2003). Entrepreneurship: A South African Perspective. Pretoria: Van Schaik.

O'Reilly, C. A., \& Tushman, M. L. (2004). The ambidextrous organisation. Harvard Business Review, 82(2), 74-81

Phillips, M., Moos, M., \& Nieman, G. (2014). The impact of government support initiatives on the growth of female businesses in Tshwane South Africa. Mediterranean Journal of Social Sciences, 5(15), 85-92.

Qi, C., \& Chau, P. Y. K. (2018). Will enterprise social networking systems promote knowledge management and organisational learning? An empirical study. Journal of Organisational Computing and Electronic Commerce, 28(1), 31-57.

Raisch, S., Birkinshaw, J., Probst, G., \& Tushman, M. L. (2009). Organizational ambidexterity: Balancing exploitation and exploration for sustained performance. Organization science, 20(4), 685-695.

Rajakumar, C. S., \& Banumathi, M. (2017). The mediating effect of organisational learning capability on high performance work system and corporate entrepreneurship relationship. International Conference on Literature, History, Humanities and Social Sciences (LHHSS-17) Jan. 1-2, 2017 Dubai (UAE).

Rashidi, M. M., Habibi, M., \& Jafari Farsani, J. (2010). The relationship between intellectual assets organisational learning capability at the institute for international energy studies. Management and Human Resources in the Oil Industry, 11(4), 59-76.

Rezaei, S., Shahijan, M. K., Valaei, N., Rahimi, R., \& Ismail, W. K. W. (2018). Experienced international business traveller's behaviour in Iran: A partial least squares path modelling analysis. Tourism and Hospitality Research, 18(2), 163-190.

Robert, J. (2010). Small business failure rates as high as $63 \%$ in first two years. Retrieved from http://www.businesslive.co.za/southafrica/sa_companies/2010/11/16/small-businessfailure-rate-63-in-first-two-years.

Rueschemeyer, D. (1977). Structural differentiation, efficiency, and power. American Journal of Sociology, 83(1), 1-25. 
Saadat, V., \& Saadat, Z. (2016). Organisational learning as a key role of organisational success. 3rd International Conference on New Challenges in Management and Organization: Organization and Leadership, 2 May 2016. (pp. 219 - 225). Dubai, UAE.

Sarwoko, E., Frisdiantara, C. (2016). Growth determinants of Small Medium Enterprises (SMEs). Universal Journal of Management, 4(1), 36-41.

Scholtz, R. (2009). Internal corporate venturing as a tool for corporate renewal (Masters dissertation, University of Stellenbosch, Stellenbosch, South Africa). Retrieved from http://hdl.handle.net/10019.1/1871

Schwab, L., Gold, S., Kunz, N., \& Reiner, G. (2017). "Sustainable business growth: Exploring operations decision-making". Journal of Global Responsibility, 8(1), 83-95.

Sharma, P., \& Chrisman, J. J. (1999). Towards a reconciliation of the definitional issues in the field of corporate entrepreneurship. Entrepreneurship: Theory and Practice, 23(3), 11-18.

Terjesen, S., Patel, P. C., \& Sanders, N. R. (2012). Managing differentiation-Integration duality in supply chain integration. Decision Sciences, 43(2), 303-339.

Thomas, A., Dorrington, P., Costa, F., Loudon, G., Francis, M., \& Fisher, R. (2017). Organisational learning capability in SMEs: An empirical development of innovation in the supply chain. Cogent Business \& Management, 4(1), 1-20

Tohidi, H., \& Mandegari, M. (2012). Assessing the impact of organisational learning capability on firm innovation. African Journal of Business Management, 6(12), 4522-4535.

Tran, T. (2008). A conceptual model of learning culture and innovation schema. International Business of Journal, 18(3): 287-299.

Ulrich, D., Von Glinow, M. A., \& Jick, T. D. (1993). High-impact learning: Building and diffusing learning capability. Organisational Dynamics, 22(2), 52- 66.

Vintergaard, C. (2006). Early phases of corporate venturing (Doctoral dissertation, Copenhagen Business School, Copenhagen, Denmark). Retrieved from https://primo.kb.dk/permalink/f/10k3fbj/CBS01000336706.

Weick, K.E. (1982). Management of organisational change among loosley coupled elements. In Goodman, P.S., Associates (eds). Change in Organisations. San Francisco, CA.: JosseyBass.

Wernerfelt, B. (1984). A resource-based view of the firm. Strategic Management Journal, 5(2), 171-180.

Wiklund, J., Patzelt, H., \& Shepherd, D. A. (2009). Building an integrative model of small business growth. Small Business Economics, 32(4), 351-374.

Yeboah, M. A. (2015). Determinants of SME growth: An empirical perspective of SMEs in the Cape Coast Metropolis, Ghana. The Journal of Business in Developing Nations, 14, 1-2.

Zahra, S. A., \& Hayton, J. (2008). The effect of international venturing on firm performance: The moderating influence of absorptive capacity. Journal of Business Venturing, 23(2), 195220. 